\title{
Firm Profitability And The Administration Of Working Capital: Delving Into A Case Of The Cement Sector Of Pakistan
}

\author{
Farhan Ullah \\ MS Scholar, CECOS University, Peshawar \\ Dr. Raza ullah \\ Assistant Professor, Department of Management Sciences \\ Islamia College Peshawar \\ raza@icp.edu.pk \\ Dr. Mustafa afeef \\ Assistant Professor, Department of Management Sciences \\ Islamia College Peshawar \\ mustafa@icp.edu.pk
}

\begin{abstract}
This study endeavors to establish an association between the administration of working capital and firm returns in Pakistan's cement sector. Ten companies listed in the cement industry of KSE 100 Index were taken from Pakistan Stock Exchange randomly. Financial data in secondary form was collected from the financial reports of cement firms of the country. The study employed return on assets as an explained variable and inventory turnover period in days, collection period in days, payment period, cash conversion cycle, sales in log, and liquidity ratios as explanatory variables while controlling for the influence offirm's size and firm's growth in terms of sales. It was found that the current ratio, log of sales, cash conversion cycle and inventory conversion period positively influenced the return of companies whereas size of the firm, collection period of receivables, payment period to creditors and the debt ratio of firms had a negative influence on it.
\end{abstract}

Key words: Collection period, return on assets, payment period, inventory turnover period, cash conversion cycle, debt ratio, sales and current ratio.

\section{Introduction}

In finance, dealing with short-lived assets and short-run debts is of utmost importance. The controlling and planning of short-term assets and debts is very vital for a decent administration of the working capital (hereinafter referred to as WC) of a firm (Eljelly, 2017). The WC shows the liquidity of a company. It pertains to the amount of cash present for daily operations of a firm. In this context, it is also sometimes known as the current capital. As a matter of fact, for maximization of firm value, an optimum magnitude of WC has to be maintained. In this regards, many research studies have been performed in the past. Meena and Reddy (2016), for instance, performed a study in India employing a ten year data of sugar mills in the private sector from 2006 to 2015. They found that a prudent administration of WCdoes influence return in a positive fashion. Similarly Iqbal et al (2015) concluded that the administration of WC in an efficient manner should be one of the main constituents of corporate strategy as it really adds to a firm's performance thereby improving the overall value of a given firm. The existing study serves an 
obvious objective, i.e., to identify the primary aspects of WC that are involved in influencing the return of firms in the perspective of the cement sector of Pakistan. There are, of course, limitations to the study. For example, the study has taken into consideration only 11 years of data. A study incorporating data for a longer period of time may offer more reliable results. Nonetheless, it is expected that the current work will give some insights to policy makers regarding how important it is to efficiently administer the WC of the country's cement sector.

\section{Review of Literature}

Over past, various researches have been performed on the interrelationship between companies' WC administration and performance of those firms. The ensuing lines present some of those earlier research endeavors. Samiloglu and Akgun (2016) performed an analysis on WC and its upshot on return and found that shareholder's worth can be augmented by shrinking the cash conversion cycle. In a similar fashion, Meena and Reddy (2016) did a research study in an Indian state named Telangana, by taking data from the sugar sector from 2006 to 2015. They too obtained an inverse link between the two variables. Iqbal and Zhuquan (2015) noted that administration of WC in an effectual way is the major aspect of corporate strategy that enhances the overall value of the firm. It was also confirmed by them that WC of companies listed in Karachi Stock Exchange affects firm return. Sharma and Kumar (2010)also conducted a study on the effect the WC of a firm has over its returns. They noticed an important link of WC with firm return. Tahir and Anuar (2015) took 127 companies listed in the textile sector in Pakistan Stock Exchange for 13 years, i.e., from 2001 to 2012, to check the impression of WC on firms return. They observed that the collection period, net WC, debt ratio, and current assets to net sales ratio had a contrary effect on the proxy of profitability.

Onodje (2014) also checked for the same association by taking a sample consisting of 75 manufacturing firms listed in Nigerian Stock Exchange. The income to sales ratio was taken as the explained variable, while quick ratio, debt to equity ratio, inventory turnover, and payment period were taken as explanatory variables. He concluded by exploring a significant relationship between the explanatory and the explained variables. No significant link was established between firm profitability and liquidity. Nasreen(2014) also attempted to explore the administration of WC's impact on company' returns. She, however, found an insignificant link between WC and ROE.

Tufail et al (2013) also have attempted to find the same relationship as found by the other researchers. They employed return on assets for computing profitability, financial leverage and current assets to total assets as a measure of a given firm's investment policy. They found that administration of WC was negatively correlated with return. Bose (2013) also did a study on the effect of administration of WC on firm return by taking nine years data of 30 firms in the manufacturing sector. He checked for the effect of the ingredients of WC on firm performance and found that the relationship was positive. Kaur and Sing (2013) also did a research to check for movements in return as a result of a good administration of WC. The findings of their research were consistent with the work of Oladipupo and Okafor(2013) who also found a significant relationship of WC and profitability. In another study, Ahmadi et al (2012) explored the link of administration of WC and profitability of firms in the Tehran food industry that were listed on the Tehran Stock Exchange (TSE). They found an inverse relationship between the components of WC and profitability.

Raheman and Nasr (2007) discussed the impact on return and liquidity owing to changes in administration of WC. They found a strong connection between firms' return and components of 
WC. In the same manner, Lazaridis and Tryfonidis (2006) also explored the link between firms return and profitability. They employed 131 firms' information from the Stock Exchange of Athens for four years, i.e., from 2001 to 2004. The results of their study showed that by keeping an optimum amount of WC components, managers can enhance their firms' returns. Filbeck and Krueger (2005) also attempted to see how an efficient administration of WC affects firms' returns. They took into their study the data of 32 US based companies. They concluded that firms' returns were improved after WC policies were changed. Eljelly (2004) studied the liquidity profitability trade-off in one of his papers and found that WC, if properly managed can definitely lead to an enhanced profitability of a given firm. Deloof (2003), in a study conducted on Belgian firms, found that one of the reasons of variation in firms' returns is the arbitrary management of their WC. Ghosh and Maji (2004) checked the impact of administration of WC in the Indian cement industry from 1992 to 2002. They found, however, that administration of WC had no significant effect on returns. Shin and Soenen (1998) also examined the way firms' returns and shareholder wealth are affected by proper administration of WC. They, however, found an insignificant association between the net trading cycle and firm profitability.

\section{Research Methodology}

Cement sector of Pakistan has been chosen as a sample for the current research. For the purpose of data collection, secondary sources were used and ten out of 24 companies listed in the cement sector of Pakistan Stock Exchange were taken for the study. The sampling duration was eleven years, i.e., from 2005 to 2015 . The dependent variable, i.e., the firm profitability was measured using the return on assets ( ROA) variable and the independent variable, the administration of WC was calculated through the cash conversion cycle (CCC). To explicate, the cash conversion cycle was further measured through three variables, i.e., the collection period (ACP), inventory turnover (ITID), and payment period (APP). The composite variable CCC was computed using the formula $A C P+I T I D-A P P$. A few other variables were controlled for the study including sales, firm size and financial assets to total assets. Regression model was employed for performing the analysis.

\section{Data Analysis}

The descriptive statistics for the explained and the explanatory variables employed in the study have been mentioned in the following table:

Table 1: Descriptive Statistics

\begin{tabular}{lrrrr}
\hline Var & Mean & Med & Min & Max \\
\hline NOP & .101 & .094 & -.176 & .409 \\
ACP & 8.079 & 6.868 & .022 & 26.903 \\
ITID & 30.008 & 26.408 & 3.335 & 96.257 \\
APP & 5.064 & 2.778 & -.411 & 19.047 \\
CCC & 29.284 & 27.126 & 1.207 & 65.688 \\
CR & 1.039 & 1.000 & .046 & 2.800 \\
DR & .475 & .150 & .001 & 2.000 \\
FATA & .086 & .049 & .010 & .298 \\
LOS & 6.612 & 6.637 & 5.119 & 7.914 \\
\hline
\end{tabular}

Looking at table 1 , it is clear that all the variables taken for the study are within their normal range and there are no extreme values seen that could significantly affect the regression results. 
Hence, we are ready to proceed now. We start with model selection since we have panel data, i.e., the one having multiple firms or units studied for multiple years.

Table 2: Selection of the Model

\begin{tabular}{|c|c|c|c|}
\hline Tests & Null Hypothesis $\left(H_{0}\right)$ & Alternate Hypothesis $\left(H_{1}\right)$ & $p$ value \\
\hline Chow & $\begin{array}{l}\text { Pooled is more appropriate } \\
\text { than FEM* }\end{array}$ & $\begin{array}{l}\text { FEM ismore appropriate than } \\
\text { Pooled }\end{array}$ & 0.778 \\
\hline Breusch Pagan & $\begin{array}{l}\text { Pooled ismore appropriate } \\
\text { than REM** }\end{array}$ & $\begin{array}{l}\text { REM is more appropriate than } \\
\text { Pooled }\end{array}$ & 0.32 \\
\hline Hausman & $\begin{array}{l}\text { REM is more appropriate than } \\
\text { FEM }\end{array}$ & $\begin{array}{l}\text { FEM is more appropriate than } \\
\text { REM }\end{array}$ & 0.56 \\
\hline
\end{tabular}

*Fixed Effects Model **Random Effects Model

The three tests mentioned above have been employed for selection of the model. The chow test has a probability value of 0.778 showing a very high insignificance level meaning that Pooled OLS is the more appropriate in contrast with the Fixed Effects Model(FEM). The $p$-value of Breusch Pagan of 0.32 is also insignificant indicating again that pooled OLS is more appropriate than the Random Effects Model(REM). The probability assessment for Hausman test is 0.56(highly insignificant). This portrays that REM is more suitable as compared to the Fixed Effects Model. However, since the pooled regression model is more appropriate than both the FEM and the REM, it is therefore concluded that the Pooled OLS model is the most appropriate one for use in this research. Rahman et al (2010) had also found pooled OLS as the best model in their study through the same process.

We now start with the regression analysis by using the pooled OLS method as suggested by the chow test and the Breusch Pagan test.

Table 3: Pooled OLS using 110 Firm-Year Observations (10 units studied for 11 years)

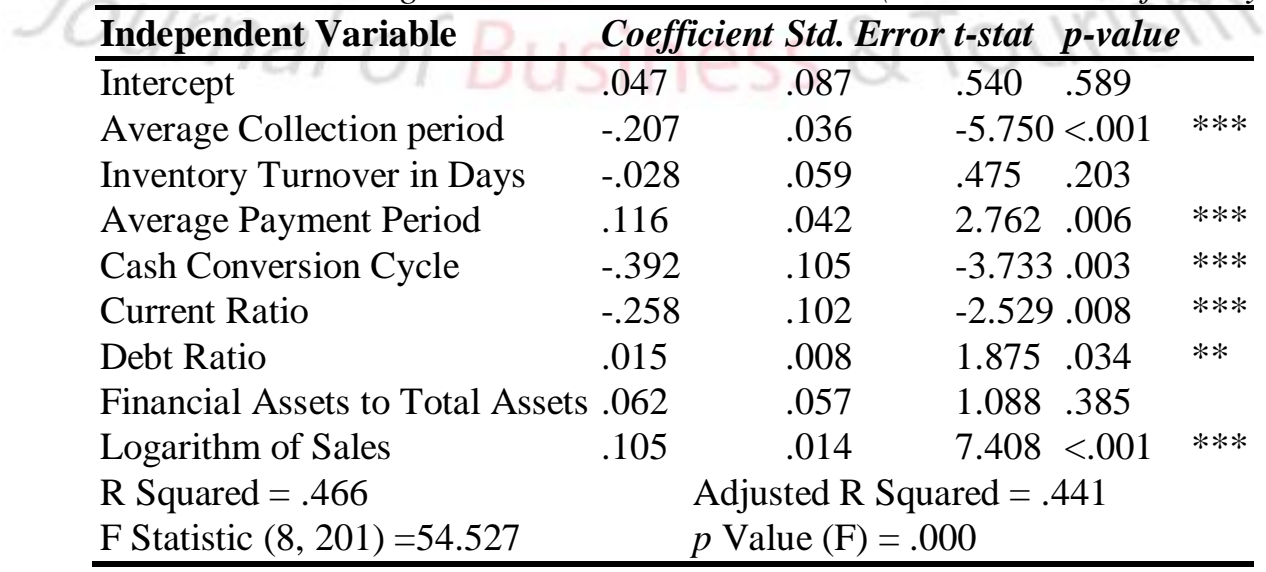

Dependent Variable: Return on Assets

The results of the regression analysis are exhibited in table 3. As can be seen, all the beta coefficients, except for those representing inventory turnover period in days and financial assets to total assets, are significant. This portrays that most of the gauges of WC administration are significantly associated with profitability. We start with the discussion of each of those relationships one by one: The average collection period in days has a negative and highly significant link with the return on assets (a proxy used for profitability) with a beta coefficient of 
-.207 ( $p$ value < .001). Inventory turnover in days, nonetheless, has an insignificant association with return variable with a coefficient of $-.028(p$ value $=.203)$. The average payment period, however, is again significantly connected to returns with a positive association of .116 ( $p$ value $=$ .006). The composite variable of administration of WC, i.e., the cash conversion cycle, also appears to have highly significant negative association with that of profitability (beta $=-.392, p$ value $=.003$ ). Based on this, we can surely conclude that the components of administration of WC are undeniably involved in augmenting firms' profitability.

\section{Conclusion}

The current study was executed to explore the link between administration of WC and returns of firms listed in the cement sector of the country. In order to control the effect of other variables that might affect profitability, current ratio, debt ratio, financial assets to total assets and the log of sales were also included in the analysis. It was observed that the indicators of WC administration, except for the inventory turnover in days, had a significant link with profitability of cement firms. In other words, a timely collection of accounts receivable and a delayed payment of the companies' accounts payable were known to have a favorable effect on returns. On the other hand, keeping inventory for the minimum possible time had no noticeable effect on returns of firms in the cement sector. Overall, however, administration of WC as measured by cash conversion cycle was found to be instrumental in determining a firm's return performance. This negative relationship of cash conversion cycle with profitability is in line with studies conducted previously including those by Deloof (2003), Shin \& Soenin (1998), and Eljelly (2004) who also came up with similar results. It can, therefore, be concluded that administration of working capital is equally relevant for the cement industry of Pakistan in terms of its importance in enhancing firms' performance.

\section{References}

Ahmadi, M., Arasi, I., \&Garajafary, M. (2012). Studying the Relationship between Administration of WC and Profitability at Tehran Stock Exchange: A Case Study of Food Industry. Research Journal of Applied Sciences, Engineering and Technology, 4(13), 1868-1874.

Bose, B. (2013). The Impact of Administration of WC Practices on Firm's Profitability. International Journal of Applied Research and Studies, 2(6), 1-15.

Deloof, M. (2003). Does WC Affect the Profitability of Belgian Firms? Journal of Business, Finance and Accounting,30(3), 573-587.

Eljelly, A. (2004). Liquidity Profitability Trade off: An Empirical Investigation in an Emerging Market. International Journal of Commerce and Management, 14(2), 48-61.

Filbeck, G., \& Krueger, T. (2005). Industry Related Differences in Administration of WC. MidAmerican Journal of Business, 20(2), 11-18.

Ghosh S. K \& Maji S. G. (2004). Administration of WC Efficiency: A Study on the Indian Cement Industry. Management Accountant Calcutta, 39(1), 363-372.

Iqbal, A., \& Zhuquan, W. (2015). Administration of WC and Profitability. Evidence from Firms Listed on Karachi Stock Exchange. International Journal of Business and Management, 10(2), 231-235.

Kaur, H. V., \& Singh, S. (2013). Managing Efficiency and Profitability through WC: An Empirical Analysis of BSE 200 Companies. Asian Journal of Business Management, 5(2), $197-$ 207. 
Lazaridis, I., \& Tryfonidis D. (2006). Relationship between Administration of WC and Profitability of Listed Companies in the Athens Stock Exchange. Journal of Financial Management and Analysis, 19(1), 26-35.

Meena, G. L., \& Reddy, I. L. (2016). The Relationship between Administration of WC and Profitability: Evidence from the Sugar Industry of Telangana State. Indian Journal of Applied Research, 6(11), 374-378.

Nasreen, S. (2014). Impact of Administration of WC on Firm's Profitability. Research Journal of Finance and Accounting, 5(11), 210-222.

Oladipupo, A.O. \& Okafor, C.A. (2013). Relative Contribution of Administration of WC to Corporate Profitability and Dividend Payout Ratio: Evidence from Nigeria. International Journal of Business and Finance Management Research, 1, 11-20.

Onodje, M.A. (2014). Administration of WC and Performance of selected Nigerian Manufacturing Companies. Global Journal of Management \& Business Research: Business, Economics and Commerce, 14(3), 40-49.

Raheman, A., \& Nasr, M. (2007). Administration of WC and Profitability: A Case of Pakistani Firms. International Review of Business Research Papers, 3(1), 279-299.

Samiloglu. F., \& Akgun. A. I. (2016). The Relationship Between Administration of WC and Profitability: Evidence from Turkey. Business and Economics Research Journal,7(2), 1-14.

Sharma, A. K., \& Kumar, Satish. (2010). Effect of Administration of WC on Firm Profitability: Empirical Evidence from India. Global Business Review, 12(1), 159-173.

Shin H. H., \& Soenen, L. (1998). Efficiency of Administration of WC and Corporate Profitability. Financial Practice and Education, 8(2), 37-45.

Tahir, M., \& Anuar, M. A. (2015). The Determinants of Administration of WC and Firms Performance of Textile Sector in Pakistan. Quality and Quantity, 50(2), 605-618.

Tufail, S., Bilal., \& Khan, Javaria. (2013). Impact of Administration of WC on Profitability of Textile Sector of Pakistan. Isletme Arastirmalari Dergisi, 5(2), 32-56. 